\title{
Counterpart funding of the Universal Basic Education in Nigeria: Implication for Counseling
}

\author{
${ }^{1}$ Dr. Anibueze, Uchenna Anselm, ${ }^{2}$ Prof. Okwo, Fredrick .O \\ ${ }^{I}$ General Studies Unit, Federal University Oye-Ekiti, Ekiti State, Nigeria \\ ${ }^{2}$ Dept. of Arts Education University of Nigeria, Nsukka
}

\begin{abstract}
This paper studied Counterpart funding of Universal Basic Education in Nigeria: Issues, Problems and Prospects. It discovered among other problems derailing the education sector, that states governments fail to meet with the obligation of raising their counterpart fund to UBE, that state governments divert federal government fund for UBE to other projects of their choice, that there is \#52 billion lying waste unutilized by state governments, which states could not access further fund for UBE because they abused the process of accessing such fund. This paper recommended for an alternative counterpart funding of the UBE scheme in Nigeria.
\end{abstract}

Keywords: Basic, Education, Counterpart, Counseling, funding

\section{Introduction}

Funding education has been a very big question that the answer has remained elusive in Nigeria. In fact from the pre-colonial era till date, funding the education sector has been a big challenge to each government that comes on board in Nigeria. Funding the education sector has been a $\operatorname{cog}$ in the wheel of education development/progress in Nigeria. Nigeria is rated among the poorest funded education sector even in Africa where she claims to be the giant.

According to Maduewesi (2001), "Public education is a capital-intensive, non-profit making social service. Technically, it is never "free" at any level. It must be paid for somehow, by somebody". In the view of king (1969), "education is after defense, the biggest single item of national expenditure" in most countries of the world, in Nigeria, this is certainly not the situation today. If anything, we have been experiencing a decline outlay for education as a percentage of the nation budget in the past ten years. For example, the figures decline from $1 \%$ in 1999 to $8 \%$ in 2000 , then $5 \%$ in 2002 and a meager $1.8 \%$ in 2003 . Any wonder then that we are having a worsening funding problem in education. The consequences are felt everywhere, hence the intensification of the crises in education sub-systems and institutions.

Nigerian governments both military and civilian are accused of underfunding the education sector. Nigeria has never met the UNO specification of $26 \%$ annual budget allocation to education. UNICEF (2005) rated Nigeria as the tenth worst and deviant country in funding education. Yet she hopes to use education as the instrument of economic, social and political development. A number of Nigerians had long seen education as the surest way of making Nigeria both free and great. They had long seen education as the catalyst to political and economic growth and development in Nigeria.

The message which Fafunwa gave us as a nation, if we would stop and listen is that in the $21^{\text {st }}$ century, nothing will be as important as the educated mind, the properly and well technologically trained mind, what he is emphasizing to us is not just the desirability of, but the utmost necessity of the highest quality and expanded dimensions of the educational effort, cast, right from the beginning, in the language in which the child grows and develops. Ocho (2001) opined, "Since education is a public good which cannot be free, all who benefit from its product should share in the cost. Therefore parents, communities, corporate bodies and the three levels of government must carry the burden of providing education for all citizens".

In order to provide education for everybody, the idea of counterpart funding was brought to focus. The remaining part of this paper on Counterpart Funding of Universal Basic Education (UBE) in Nigeria: Issues, Problems and Prospect will examined the following; UBE, Funding the UBE in Nigeria, Counterpart funding, where do the fund come from, how to raise funds from the various groups, the volume of funds for UBE, problem of UBE in counterpart funding alternative counterpart funding, recommendations, conclusion.

\section{Universal Basic Education}

The former President of the Federal Republic of Nigeria, Chief Olusegun Obasanjo on $30^{\text {th }}$ September 1999, as a matter of policy formally launched the Universal Basic Education (UBE) programme. The vision and mission of the universal basic education (UBE) are clearly set in the implementation blue print for the universal basic education (UBE) scheme. Basic Education is the foundation for sustainable lifelong learning which would 
provide reading, writing, and numeracy skills. According to Ogbonna (2001) "the rationale for embarking on the UBE scheme is based on the fact that Nigeria is a signatory to the 1990 Jomtien declaration of education for all by the year 2015, and a member of the total eradication of illiteracy".

The federal ministry of education (2000) in its implementation guidelines for the universal basic education (UBE) programme enumerated the following objectives of the UBE as follows

1) Developing in the entire citizenry a strong consciousness for education and a strong commitment to its vigorous promotion.

2) The provision of free universal basic education for every Nigerian child of school going age.

3) Reducing drastically incidence of drop-out from the formal school system (through improved relevance quality and efficiency)

4) Catering for the learning needs of young person's who for one reason or another had to interrupt their schooling through appropriate forms of complementary approaches to the provision and promotion of basic education.

5) Ensuring the acquisition of the appropriate levels of literacy, numeracy, manipulative, communicative and life skills as well as the ethical, moral and civic values needed for laying a solid foundation for life-long learning.

Following the Jomtien recommendation that basic education should not be considered as a static term, but as a process to be determined by every nation according to its evolutionary development needs). Basic Education is seen by Obasi (2001) in the Nigeria context and to encompass the following:

1) Programme / initiatives for early childhood care and socialization

2) Education programmes for the acquisition of functional literacy, numeracy and life skills, especially for adults (persons aged 15 and above)

3) Out of school, non-formal programme for up-dating the knowledge and skills of person's who left school before acquiring the basic needs for life-long learning.

4) Special programmes for nomadic populations

5) Non-formal skills and apprenticeship training for adolescents and youth who have not had the benefits of formal education.

6) The formal school system from the beginning of primary education to the end of the junior secondary school.

Universal Basic Education (UBE) was established because the estimate of illiteracy rate in Nigeria still stands at 52\%. Education statistics for 1996 shows that only 14.1 million children are enrolled in primary school out of over 21 million children of school age. The completion rate was $64 \%$ while the rate of transition to junior secondary school was $43.5 \%$ (UBE document, 1999). This in actual fact is not the first time Nigeria is embarking on a universal education scheme aimed at providing free and qualitative education for all.

The UBE programme is aimed at seeing the Education sector from the rot and decay of the past. It is meant to expand the focus of the failed UPE scheme of 1976. It is expected that UBE programme will provide qualitative, functional, free, and compulsory education to every Nigerian child from primary to junior secondary level. This change in our educational system from 6:3:3:4 to 9:3:4 Systems. According to the president at the launching ceremony, about $50 \%$ of school age (6 years to 18 years) children in Nigeria are out of school.

UBE starts from primary one to third year of junior secondary school for the children. It also includes an informal education component, for children from about 6 years to 15 years. The UBE non-formal education includes nomadic education and education for fishermen children. The UBE programme is intended to be universal, free and compulsory. These terms imply that appropriate types of opportunities will be provided for the basic education of every Nigerian child of school going age; that parents have an obligation to ensure that children in their care avail themselves of such opportunities, and that sanctions will be imposed on persons, societies and institutions that prevent children, adolescents and youths from benefiting from UBE (Obasi, 2001)

According to Adamechi \& Romaine (2000), the UBE is the brain child of the federal government, for this reason, it is expected that the federal government will provide at least $65 \%$ of the total fund needed for the successful implementation of the scheme, while the various states and local governments will contribute to the balance of the $35 \%$. Basic Education is the bona-fide-right of every citizen of Nigeria. The federal government established some agencies that facilitate the implementation of the programme. These agencies include the Education Tax Fund, established by Decree No. 7, 1993. According to the National chairman of Education Tax Fund, the Board was assigned to manage and utilize the $2 \%$ Education Tax collected by the Federal Inland Revenue Services (FIRS), for the purpose of upgrading of educational physical infrastructure throughout the country and in the three tiers of educational institutions run by government (Olakunri, 1999) 


\section{Counterpart funding the UBE in Nigeria: Issues and Problems}

Counterpart funding is about two people or groups of people, associations, institutions, governments agreeing on modalities to finance or raise fund to execute a project or programme that both are interested in or that which they have common interest.

Counterpart funding of education in Nigeria is not a new terminology or ideology. The colonial masters brought the idea of grants in aid to assist individuals', organizations, churches, towns etc at the inception of formal education in Nigeria.

Education is a huge venture that demands big task, which means that a single individual cannot execute it. According to Nwosu cited in Adamaechi(2000)' Education cannot be free, meaning that education cannot be provided without any cost. Somebody or some people must pay for it somehow, somewhere"

In Sudan the global Education cluster, with UNICEF and save the children as co-leads, is undertaking an ambitious and exciting project to map global capacity in Emergency Education Preparedness and Responseat global agency level and in a few select countries.... State ministry of Education in south Darfur also promised US \#1.5 Million as counterpart funding for the UNICEF/EMOGE Annual work but that commitment has not been materialized due to the chronic lack of support from other ministries and overall low investments in education.

In 2000, the then president Obasanjo and director-general of UNESCO agreed that UNESCO would continue its collaboration with Nigeria as provided for in the special Action plan established in 1999 and on the basis of Resolution 56 adopted at the $30^{\text {th }}$ session of the UNESCO General conference. During this meeting, president Obasanjo requested the Director-general that UNESCO assumes an important role in the effort deployed by the government of Nigeria to design a sound education policy and to prepare a comprehensive development programme based on UBE.

There are five components for the implementation of this activity:

- Improving community education and literacy using the media

- Improving capacity for local-level management: the federal Ministry of Education is leading the programme for co-operation while UNESCO works in collaboration with Nigerian officials and educators are to plan and implement the programme, which will be carried out in two phases.

The proposed budget amounted to US \$3million over a three year period. UNESCO provided US $\$ 700.00$ to implement phase 1 from regular programme funds. The government of Nigeria has approved US\$ 800,000 for the improvement of the inspectorate. UNESCO has assisted in mobilizing the remaining US\$1.5million from extra budgetary sources. The UNESCO office in Abuja is responsible for coordinating inputs, including technical backstopping from UNESCO headquarters...... the slow pace of the activities is due to lack of provision of agree-upon counterpart funds. It was agreed that the government of Nigeria would make those funds available in good time so as to enable the programme to be implemented successfully.

Idoko (2008) stated that one thing however, remains undisputable that whatever efforts being made by the federal, state and local governments in the country at revamping the nations education system without first strengthening the foundation structure of basic education in the country, will be futile. Idoko pointed out that one of the greatest challenges the commission was facing is the lack of political will by some leaders to draw its matching grant for implementation of the UBE programmes in their states. Also he has all the time lamented the refusal of some state governments to pay their counterpart fund. For instance, he said "as at the end of 2008, Edo state had still not accessed third and fourth quarter intervention fund of 2005 and four states have not accessed third and fourth quarters intervention fund, which include: Bayelsa, Cross River, Delta and Edo. Nwankwo (2009), a director with the presidency in an annual lecture delivered to the Nigerian Academy of Education Abuja lamented that UBEC has \#52 billion fund not accessed by states in Nigeria to fund education. What is the reason for not accessing this fund?, your guess is as good as mine, lack of political will to raise the counterpart fund, the inability of states to retire the initial grant from the federal government, poor inspection by the federal government on the utilization of the UBE fund, lack of involvement of other stakeholders such as Parents Teachers Association, towns, organizations, other parties, private individuals and organizations, etc.

\section{The Nigeria Education System}

According to a recent Nigeria Demographic Health Survey, only 43 percent of children in the North West and 42 percent in the North East are actually attending school. Even in the Southern zones, up to $20 \%$ of the pupils are not actually attending school. The Federal Ministry of Education has calculated that over seven million primary school aged children are out of school and over 60 percent of these are girls.

A common feature at both primary and secondary school levels are dilapidated and overcrowded classroom building where, even textbooks, libraries, laboratories, computers and recreational amenities are either inadequate or not provided at all. Qualified teachers are insufficient, unprepared, absent from classes or not serious in lesson delivery. 
All these problems have consciously affected the performance of the Nigerian students at all levels. A survey of student's performance in the Senior Secondary School Certificate Examination in the past five years indicates that they have not got beyond 26 percent in the number of candidates that obtained credit in English language, mathematics and other three subjects. Their performance in NECO is not better either. The year 2010 recorded the failure rate 83.42 percent and painfully as many as 74.956 students engaged in examination malpractice. In 2011, only 10\% of all that sat for NECO examination were successful in English and Mathematics. This indicates an increase in the failure rate of 6.58 between two successive years. What this portends is a weak foundation for university admission, compounded by recurrent malpractices in the post-UME. Since 2003, less than 15 percent of candidates that apply are offered admission into the nation's universities. The Academic Staff Union of Universities (ASUU) maintained that universities are underfunded and lecture-student ratio doubled the UNESCO norm of 1:10. For four months, ASUU went on strike in 2009. Promotion of teaching and research is at the lowest ebbs in the universities.

Hans (1961) has linked the quality and structure of national systems to the percentage of national revenue spent on education, and according to him;

The percentage of national revenue spent on education, the division of burdens between the central and local authorities and the system of grants adopted by the government are all reflected in the structure and quality of national systems.

The federal allocation to education often appears staggering though always a far cry from the $26 \%$ of the budget suggested by UNESCO for education. In 1991 for example, \#1.8 billion or $4 \%$ of the budget was allocated to education, placing fifth highest in sectoral allocation Agriculture and Rural Development $22 \%$, Defence, 9.2\% Federal Capital Development Authority, 8.8\%. Works and Housing, 6.6\%. (Approved Revenue Recurrent and Capital Estimates, 1991 ). This is not the whole story. Each states and local government allocates a significant proportion of its revenue to education, progressive communities spend money to erect and maintain school buildings, award scholarship or purchase school equipment. Above all, parents spend a lot of money for the education of their children. When all these expenses are put together and considered, it will be correct to say that more money is spent on education than on any other sector. However, it is difficult to know what proportion of the expenditure which government allocates to education is actually or wisely spent. For example, Aleyideino (1991) pointed out that federal grants spent on erecting temporal classroom accommodation in Kaduna State for the Universal Primary Education went down the drain because of poor quality work which led to the collapse of the building a short time after completion. Worse things happened in many other states where money was claimed for non-existent buildings.

Ukeje (1991) is of the opinion that most of our educational institutions are substandard largely because of poor financing. He concluded ... education is the key that unlocks the door to modernization, but the quality and efficiency of the key depend largely on its design and fabrication both functions of financial provisions. Clearly we cannot have quality education without adequate funding. There is the need for improved funding of the UBE.

\section{What is the Volume of Funds for UBE}

It has not been easy to have a reliable and comprehensive statistics of amount of funds coming from government to education sector (Hencliffe 2002 cited in Okeke, 2005).

The Federal Executive Council approved the criteria for fund utilization of UBE intervention fund to the states and Federal Capital Territory as pre-primary Education (5\%); primary Education (6\%) and junior secondary level $(35 \%)$.

The 2\% of the CRF amount in 2005 and 2006 financial years;

I. was $\# 24,300$ billion in 2005

II. \#30,480 billion in 2006 and is to be

III. \#35 billion in the 2007 budget

The $2 \% \mathrm{CRF}$ is disbursed to the states in the following proportions:

1. $70 \%$ matching grant (i.e. fund contributed by both Federal and state government, on equal basis).

2. $14 \%$ fund to address Educational Imbalance among and within states.

3. $50 \%$ funds for the implementation of the home crown school feeding and Health programme (HGSF \& $\mathrm{HP})$

4. $50 \%$ incentive to states for good performance

5. $2 \%$ funds for the education of the physically and mentally challenged children

6. $2 \%$ funds for monitoring of UBE programmes. 


\section{Where do the Funds come from?}

The Education decree No of 1992 stipulates that all companies operating in Nigeria with a minimum of 100 employees are required to contribute 2.0 percent of their pre-tax earnings to the Education Tax Fund for the purpose of funding Education (Okeke, 2005, UBE, 2004).

Federal intervention in UBE will be funded through:

I. Not less than $20 \%$ of the Consolidated Revenue Fund (CRF) of the Federal Government;

II. Funds/Contributions in form of Federal Government Guaranteed credits;

III. Local/international donor grants;

IV. The federal intervention fund to states will be used for the purpose of broadening access improving quality and ensuring equity in basic education, but not for teachers' emoluments and overload costs. The components are as follows:

1. Substantial party of the CRF will be disbursed to states as matching grants;

2. Part of it will be disbursed to states for special intervention to support

a) Initiatives by states to correct educational imbalance up to 2010;

b) Efforts by states to provide special education for the physically and mentally challenged;

c) Efforts by states to implement school feeding program.

d) Disbursement of funds to states will be through SUBEBS, for renovation, construction, furnishing,

3. Disbursement of grants to states will be dependent on the provision of $50 \%$ counterpart funds by states

4. UBEC may withhold further disbursement to a state if it is not satisfied that funds earlier disbursed had been judiciously utilized.

5. To access the funds, states shall

6. Present acceptable annual implementations plans based on EFA/MDGS and those projects and program that address their peculiar educational problems (UBEC, 2004).

Funds allocated to be distributed to the various tiers of education- primary, secondary and tertiary. State governments also fund education. Their source is primarily their allocation from the federal account, their state VAT and state generated revenue through local taxes, school levies etc. States fund mainly secondary level of education and a significant part of tertiary education which the state established themselves. Earlier than April 2002 , they were not involved in funding primary education when funding meant for primary education was not channeled to states. But since April 2002, states control and fund primary education with funds sent specifically for primary education through UBEC. Local governments are also involved in funding education at the primary school level. Local government revenues come from statutory allocations from Federal Account proceeds from VAT and internally generated funds. More funds should be raised for properly implementation of the UBE.

\section{Counseling to Raise Funds from the Various Groups}

The fund to be raised from these groups for the implementation of the Universal Basic Education is referred to as (UBETF) Universal Basic Education Trust Fund. Adamaechi, and Romanine, (2000),said that such fund include;

a. Civil Servants in each state should be made to pay a stipulated amount deducted from their salaries and paid into the (UBETF) account in an agreed government bank.

b. Banks/industries/companies and other commercial houses, should be assessed and asked to pay in a stipulated amount into the (UBETF) account.

c. Trade Unions- although it is always difficult to collect money from trade unions because the government does not have direct control over their business, states and local governments should look for a way to collect certain amounts in the form of rate and pay same into the (UBETF) account.

Community Development Union - All community development unions should raise fund for

UBETF. This fund may be managed by states for improving basic education.

\section{Problems of UBE Counterpart Funding}

There are constraints in the funding of UBE:

a) Lack of adequate funding of the government: Most of the activities of the Universal Basic Education are grounded due to inadequate funds. At present the Commission is relying on the World Bank credit (PEP) to fund most of its activities. What happens when it expires?

b) Lack of adequate publicity to project the image of the UBE program. The program has been stigmatized by some people as a 'white elephant' project of Obasanjo administration, which will not satisfy the yearning of Nigerians.

c) Misunderstanding of the role of the federal government in the UBE by states and local governments.

d) Endemic problem of lack of accurate, comprehensive and up to date statistics on expenditures is a constraint since such data is essential for realistic budgeting. 
e) There is total imbalance in the administrative cost of teaching and non-teaching education functionaries such that more funds that is required is sent on services of non-tutorial staff (Lab attendants- but not for teaching and learning).

f) Doubtful integrity of some of the managers of educational funds, when part of the money appropriated for education needs is misappropriated, mismanaged inadequacy of funds sets in.

\section{Counseling for alternative Counterpart Funding}

Since states fail to provide their own counterpart fund, the federal government may have to adopt alternative counterpart funding arrangement. The federal government may have to provide physical facilities such as; buildings, equipments, instructional materials, while states and local governments will provide manpower. By this arrangement, the problem of unaccessed fund will be eradicated. Memorandum of understanding may be signed as a show of commitment to both parties to this arrangement. This understanding may be made binding on each other that a renegade can be compelled by suit and court order.

\section{Conclusion}

More funds for education are an imperative demand for the internal efficiency of the system, and socioeconomic survival of the nation. Not only should we tap effectively the usual sources of funding, we must remember that the issue are not merely the quantum of money supplied, but also its purchasing power in the context of the minimum fund needed for effective performance, corruption, high inflation, and unstoppable increases of staff and students population.

Education is a necessary investment by society for its own perpetuation and improvement. The Western type of education adopted by Nigeria has become very costly to run because of too rapid expansion at all levels of the system. It has become doubtful whether society is receiving value for its investment because the quality of education is believed to be deteriorating. So far there has not been found a less costly alternative to institutionalized education.

Since education is a public good which cannot be free, all who benefit from its products should share in the cost? Therefore, parents, communities, corporate bodies and the three levels of government must carry the burden of providing education for all citizens, they should be encouraged to provide theirs through the provision of facilities, and that is counterpart funding.

\section{References}

[1] Adamaechi, B.C and Romanine, H.A (2000) Issues, problems, and prospects of free, compulsory and qualitative education in Nigeria. Universal Basic Education (UBE). Onitsha: Nigeriana Educational Pulishers ltd.

[2] http://udonna.instablogs.com/entry/the-success-of-universal-basic-education-in-nigeria

[3] Ipaye, B (1996). The Fafunwa phenomenon in Nigeria Education: Lagos Printserve Ltd

[4] Nwagwu, N.A (2003). Crisis in the Nigeria Education System. World Council for Curriculum and Instruction (WCCI) Nigerian Chapter: Second biannual lecture hosted by the Lagos branch at the University of Lagos, Akoka, Lagos.

[5] Ogunsola, T. (2009). The Nigerian Education Times (Special Award Edition): 